\section{Conflict persistence and the role of third-party interventions}

Yang-Ming Chang, Shane Sanders, and Bhavneet Walia

$\mathrm{T}$

he persistence of war is a central issue in conflict studies. In addition to the sizeable direct human toll of warfare, persistent conflict creates a host of social and economic problems in the region of conflict. Paul Collier finds that GDP declines in a country by 2.2 percent, on average, during periods of civil war. This is due to loss of production and of capital stock in warfare. Therefore, each day of war puts the conflict at a lower economic starting point in the aftermath of conflict. ${ }^{1}$

As peace-minded third parties, such as the United Nations, become more active in protecting regions against the ravages of ongoing conflict, it is important, from an allocative standpoint, that a firm understanding is developed as to which emerging conflict situations are likely to persist if left alone. A number of conflict models have made significant strides in addressing this issue. Many such models follow a contest approach by assuming that the probability of victory for each party to a conflict is governed by a Tullock contest success function. Such a function treats the probability of victory for a party as equal to a ratio of own party arms spending to aggregate arms spending for a conflict, where the effectiveness of a unit of arms spending can depend upon a party's status (defender or challenger) and strategic or military effectiveness. The contest approach is quite useful and has been employed in many areas of economics (e.g., rent-seeking, sibling rivalry, sports, and conflict). It provides a reasonable first- and second-order qualitative assumption as to the interconnected objectives of two or more parties to a contest (conflict) for economic rents. Hirshleifer was among the first to introduce the contest approach to the study of conflict. ${ }^{2}$

One downside of this approach to conflict modeling is that it limits the additional complexity that a model can assume. For example, the nonlinearity of a contest success function makes it difficult or impossible to solve in an iterated manner. Thus, no contest model of conflict appears to tell the whole story of dynamic conflict. Rather, it is more likely that each such model provides a reasonable description of an aspect of war. In this article, we focus upon theoretical conflict studies that use a contest approach and that address one of two particular aspects of national or international conflict, namely, conflict persistence and a third-party's potential effect upon conflict persistence and outcome.

Civil conflict and the persistence of war

Gershenson and Grossman develop a rational-choice model to identify the determinants of intrastate conflict within a two-party model of conflict. ${ }^{3}$ In explaining the onset and persistence of intrastate conflict, their model focuses on the values, intrinsic and economic, that rival parties place on political dominance. This model pays particular attention to what might happen in the case that a rebellion occurs and the rebel group wins state control. At such a juncture, the party from which control was wrested can choose either to fight for repossession or to acquiesce to the opposing party's

rule. Within the Gershenson-Grossman model, a fight for repossession implies that the conflict will be never-ending (i.e., neither side will effectively deter the opposing party) in the absence of outside intervention. The authors show conditions under which never-ending conflict occurs. Their main conclusion is that conflict will persist when opposing parties are sufficiently similar in terms of the value they attach to political dominance. That is to say, a party will not achieve optimal deterrence of its opponent unless it is able to "borrow upon" superior future rents from political dominance to allocate a (sufficiently) stronger fighting force.

From the policymaker's standpoint, Gershenson and Grossman suggest that a group's human capital level plays a large role in determining its value for political dominance. If one group has a higher general level of human capital, then its alternatives to political rule (i.e., emigration from the state) are more lucrative. Of course, human capital formation itself certainly depends on which group was in power over past periods. The simple (i.e., non-dynamic) model put forward by Gershenson and Grossman cannot capture such a dynamic process. ${ }^{4}$ However, one can think of the level of human capital a party would have in the absence of future political control as influencing the party's present value of political control. A group with greater human capital levels in such a scenario will possess a lower value for political dominance, ceteris paribus. Further, a group with a relatively strong preference for a particular religious or social agenda will value political dominance more highly, ceteris paribus. Lastly, if one of the two conflicting groups faces economic sanctions, its appropriable economic rents from political power will be relatively small. Therefore, if two conflicting parties are sufficiently similar in terms of human capital and socio-religious fervor, Gershenson and Grossman predict a longstanding war that carries with it significant social costs. But the third factor considered indicates that targeted, third-party sanctions can be used to potentially end a stalemated conflict Although their model is quite simplified in that it assumes two homogeneous players, Gershenson and Grossman shed light upon why many parts of Africa have been historically "cursed" by resource abundance. Resources, such as diamonds, provide 
strong incentives for two parties to engage in a bloody contest for political dominance. However, these incentives are virtually undifferentiated across party, leading to longstanding civil strife in many such areas.

Persistent civil strife in Sierra Leone, Liberia, and Angola in recent decades has matched the Gershenson and Grossman profile of never-ending conflict quite well. In the Sierra Leonean civil war (1991-2002), for example, the opposing parties were similar in many respects. Although the Revolution United Front (RUF) began with a group of university students, its main recruits-diamond workers and other subsistence laborers - were almost indistinguishable from state-led forces in terms of human capital levels. Further, opposing parties to the Sierra Leonean conflict were similarly void of strong religious or social motivations but rather fought to appropriate economic rents from control of the diamond mines. As these potential rents were nearly identical across party (i.e., each party possessed a similar technology for extracting and distributing the uncut diamonds), neither side was sufficiently differentiated to deter its opponent.

Building upon the work of Gershenson and Grossman, a study by Chang, Potter, and Sanders develops a model of territorial dispute to further study the issue of conflict persistence. As in Gershenson and Grossman, the authors model conflict as a sequential move arming game, in which a potential challenger responds to the arming levels of a defending party. Although still two-party in nature, the model recognizes that parties to a civil war can differ in terms of their military or strategic effectiveness (i.e., expected return per unit of a military good) and unit cost of arming. As stated in Chang, Potter, and Sanders: "Identity parameters allow for the possibility that military effectiveness differs across parties. For example, in 1940, invading German forces used superior blitzkrieg tactics to overwhelm Allied forces in France despite the fact that military resources between the two sides were roughly equal." Further, conflicting parties might possess different arming costs if one party has a more developed industrial base or better terms of arms trade. The authors find that persistent conflict occurs when two parties are sufficiently close in terms of military effectiveness, unit cost of arming, and value of political dominance. Without an advantage in one of these areas, it is not economically profitable for a party to deter its adversary. This finding is noteworthy from a policy standpoint in the sense that the cost of arming and military effectiveness can be endogenized by a third-party whose goal is to break a stalemated conflict. The authors also consider the role of state infrastructure depreciation in the persistence of conflict. Said depreciation can break a stalemated conflict by driving out parties seeking material value, rather than intrinsic value, from the conflict state. ${ }^{5}$

Although the two highlighted papers have much to say about conflict persistence, there are drawbacks to the type of modeling adopted. As stated, the piece by Gershenson and Grossman assumes that parties are quite symmetric in terms of fighting effectiveness, and both models assume that there are only two parties to conflict. In addition, both models assume myopic group decisionmaking. That is to say, a party to conflict in either of the studies does not take a long-term view toward state control. Rather, such a party worries only about securing state control for next-period rule. This simplification is made due to the complexity of the contes approach within a dynamic model (i.e., one in which agents maximize expected utility over a lifetime of future periods). Also, these models do not address the sustainability of a conflict equilibrium. This is a practical consideration given intermittently persistent conflicts in countries such as Sierra Leone, Liberia, and Angola during recent decades.

\section{The political economy of third-party intervention}

Many papers in the literature have addressed the role and effect of third-party intervention in conflict. A common issue of concern is why third parties intervene. Indeed, we cannot determine whether an intervention is successful without understanding its underlying motivation. While some third-party interventions have the goal of conflict management (i.e., United Nations peacekeeping missions), such a motivation does not, by any means, drive all third-party action. Many studies contend that outside nations choose to intervene when their own national interests are at stake. Regan considers this view as the "paradigm of realism" and identifies it as the dominant philosophy in international politics. In a study on the historical nature of third-party intervention, Morgenthau states: "All nations will continue to be guided in their decisions to intervene ... by what they regard as their respective national interests." 6

It is important to note that a nation's interests may not always be consistent with international peace. Unsurprisingly, most models that adopt the realist perspective find that third-party influence on the persistence and outcome of conflict is ambiguous.

Gershenson adopts a largely realist view of conflict in a study of economic sanctions amidst conflict, where economic sanctions are defined as trade restrictions imposed upon a group with the design of weakening that group's economic output. Gershenson states that: "In general, sanctions can be imposed against diverse countries, and the objectives of the party imposing sanctions vary considerably from one episode to another." He further assumes that the objectives of the party imposing sanctions are based upon that party's underlying interest in what it views as a desired outcome. Gershenson uses a contest approach to examine the effectiveness of sanctions that target one party to civil conflict. Specifically, Gershenson takes a case in which an intervening party sanctions a conflict state each time a particular party is in power. If sufficient in magnitude, he finds that targeted economic sanctions can tip the balance of a conflict in a way that is desired by the intervener. However Gershenson also finds a perverse outcome of sufficiently "weak" targeted sanctioning, in which the intended beneficiary party does not obtain (or retain) state control, and sanctions act to hurt this party. As he admits in the paper, his model does not provide 
a complete theory of sanctions. As the third party is exogenous (i.e., not prescribed a specific objective function pertaining to the conflict), the model is more useful in explaining how civil sanctioning works as opposed to the specific geopolitical motivations for its undertaking.

In a second paper, Chang, Potter, and Sanders also consider a contest model of conflict intervention. The authors observe that third parties, operating as realist scholars predict, will manipulate a conflict in any way that meets their objectives. Specifically, the authors develop equilibria that are consistent with particular third-party objectives. If a third party values the status quo sufficiently, it can either deter rebellion or make rebellion less likely to succeed. If a third party values a change of the status quo sufficiently, it can motivate rebellion. Although intuitive, this theoretical result shows that an intervener following its national interest can have several disparate effects upon the equilibrium outcome of a conflict. The paper therefore calls into question many empirical studies, such as that by Regan and Stam, assuming all interveners to be peace-minded conflict managers. Indeed, there are examples of interveners admitting that their actions follow realist motivations. During the cold war, for example, internal documents show that the Soviet Union intervened militarily on behalf of Afghanistan's ruling Marxist government not to promote peace in the region but to protect its own national security against anti-Soviet forces. ${ }^{8}$

Some noteworthy contest models of conflict intervention follow the idealist paradigm. This paradigm assumes that an intervener wishes to promote peace in a conflict state. Papers following the idealist paradigm generally focus upon how such a third party can most efficiently manage a conflict for the purpose of peace promotion. The idealist paradigm is not without basis. The United Nations has conducted 63 peacekeeping missions since 1945. Such missions, which have occurred both in the shadow of conflict and amidst fighting, feature the explicit goal of conflict prevention and management. Siqueira explores the efficacy of third-party interventions that seek to prevent or end a two-party, civil conflict. Within his model, interveners either seek to influence the costs or benefits of conflict, where said costs and benefits are specified according to a standard contest model. Among other modes of intervention, he analyzes outside efforts to raise the marginal cost of arming. Siqueira warns that there are significant indirect effects associated with conflict intervention, as parties to a conflict react to one another strategically. A conflict manager must recognize such effects in order to accurately estimate the total influence of an intervention policy. As in the case of many other contest models of intervention, Siqueira's model fails to address under what conditions a third-party would choose to intervene in the interest of conflict management.

In a work by Amegashie and Kutsaoti, the intervening party acts as a conflict manager of the social planning variety. Rather than assume that peace is ideal, the third party influences conflict to maximize a weighted sum of utilities for the parties to conflict and the noncombatant population. The authors find that outside parties can achieve such a goal through biased (i.e., one-sided) or unbiased intervention efforts.
In viewing conflict intervention as almost an extension of market regulation, Amegashie and Kutsoati are able to achieve new insights into effective conflict management. Namely, they focus not only on the conditions for a peaceful outcome to conflict but also upon the valuations associated with such an outcome. Many studies of conflict management, e.g., Regan and Stam, address the issue of creating a quick peace without assessing the values, albeit the stability, attached to a particular peaceful equilibrium. As African states such as Sierra Leone, Angola, and Liberia have encountered intermittently persistent conflict in recent decades, additional work is necessary to understand the stability of a peaceful equilibrium. ${ }^{10}$

\section{Concluding remarks}

This article discusses the contributions and limitations of the contest approach to theoretical conflict research. Specific topics of discussion herein include the persistence of war and the motivation and effect of third-party intervention in altering the outcome and persistence of conflict. The persistence of intrastate conflict and the political economy of third-party interventions are central issues in international politics. Gershenson and Grossman, and Chang, Potter, and Sanders find that conflict persists when neither party to the fighting is sufficiently differentiated to "borrow upon" future ruling rents and optimally deter its opponent. ${ }^{11}$ Third-party intervention aimed at breaking a persistent conflict should focus upon creating differences across parties in factors such as the value of political dominance, effectiveness of military arms, and cost of military arming. There are limitations to these works and to contest models of conflict in general. These models do not address the sustainability of a conflict equilibrium. This is a practical consideration given intermittently persistent conflicts in countries such as Sierra Leone, Liberia, and Angola during recen decades. Also, the studies feature a two-party model of conflict, in which parties to conflict are short-sighted (i.e., do not see beyond the next period when making present conflict decisions). This short-sightedness is often necessary within contest models due to the analytical complexity of contest success functions.

The article also discusses the effect of outside intervention upon conflict persistence and outcome. Of particular interest is a work by Amegashie and Kutsoati, who not only identify a peaceful equilibrium but discuss the degree to which a particular peaceful equilibrium is valued. Considering the value of a peaceful equilibrium may be a first step toward understanding the stability of peace. There are several issues related to civil conflict and third-party intervention that remain to be examined in future research. For example, destruction of resources in conflict is an important factor in the consideration of conflict persistence. A model that acts to endogenously account for the destructiveness of conflict would have descriptive and predictive value. Further theoretical research might explain how a peace-valuing, unbiased third party affects the outcome of intrastate conflict. 


\section{Notes}

Yang-Ming Chang is Professor of Economics in the Department of Economics at Kansas State University, Manhattan, KS, U.S.A. He may be reached at ymchang@ksu.edu. Shane Sanders is Assistant Professor of Economics in the Department of Finance and Economics, College of Business Administration, Nicholls State University, Thibodaux, LA, U.S.A. He may be reached at shane.sanders@nicholls.edu. Bhavneet Walia is Assistant Professor of Economics in the Department of Finance and Economics, College of Business Administration, Nicholls State University, Thibodaux, LA, U.S.A. She may be reached at bhavneet.walia@nicholls.edu.

1. Collier (1999, p. 175).

2. Tullock (1980); Hirshleifer (1989). See Garfinkel and Skaperdas (2007) for a systematic review of studies on the economics of conflict.

3. Gershenson and Grossman (2000).

4. Thank you to an anonymous referee for suggesting the endogenous nature of this relationship.

5. Chang, Potter, and Sanders (2007a); quote from p. 186.

6. Many studies: e.g., Morgenthau (1967); Bull (1984); Feste (1992). Regan (1998). Quote from Morgenthau (1967, p. 430).

7. Gershenson (2002); quote from p. 185.

8. Chang, Potter, and Sanders (2007b); Regan and Stam (2000).

9. Siqueira (2003).

10. Amegashie and Kutsaoti (2007).

11. Gershenson and Grossman (200); Chang, Potter, and Sanders (2007a).

\section{References}

Amegashie, J.A. and E. Kutsoati. 2007. “(Non)intervention in Intra-State Conflicts." European Journal of Political Economy. Vol. 23, pp. 754-767.

Bull, H. 1984. Intervention in World Politics. Oxford, UK: Clarendon Press.
Chang, Y.-M., J. Potter, and S. Sanders. 2007a. "The Fate of Disputed Territories: An Economic Analysis.” Defence and Peace Economics. Vol. 18, No. 2, pp. 183-200.

Chang, Y.-M., J. Potter, and S. Sanders. 2007b. "War and Peace: Third-party Intervention in Conflict." European Journal of Political Economy. Vol. 23, No. 4, pp. 954-974.

Collier, P. 1999. "On the Economic Consequences of Civil War." Oxford Economic Papers. Vol. 51, pp. 168-183.

Feste, K. 1992. Expanding the Frontiers: Superpower Intervention in the Cold War. New York: Praeger.

Garfinkel, M.R. and S. Skaperdas. 2007. "Economics of Conflict: An Overview," pp. 649-709 in T. Sandler and K. Hartley, eds. Handbook of Defense Economics. Vol. 2. Amsterdam: Elsevier.

Gershenson, D. 2002. "Sanctions and Civil Conflict.” Economica. Vol. 69, No. 2, pp. 185-206.

Gershenson, D. and H.I. Grossman. 2000. "Civil Conflict: Ended or Never Ending?" Journal of Conflict Resolution. Vol. 44, No, 6, pp. 807-821.

Hirshleifer, J. 1989. "Conflict and Rent-Seeking Success Functions: Ratio vs Difference Models of Relative Success.” Public Choice. Vol. 63, pp. 101-112.

Morgenthau, H.J. 1967. “To Intervene or Not to Intervene.” Foreign Affairs. Vol. 45, pp. 425-436.

Moseley, A. 2006. "Political Realism." The Internet Encyclopedia of Philosophy. http://www.iep.utm.edu/p/polreal.htm2006 [accessed 23 July 2006].

Regan, P. 1998. "Choosing to Intervene: Outside Intervention in Internal Conflicts." Journal of Politics. Vol. 60, No. 3, pp. 754-759.

Regan, P. and A.C. Stam. 2000. "In the Nick of Time: Conflict Management, Mediation Timing and the Duration of Interstate Disputes." International Studies Quarterly. Vol. 44, pp. 239-260.

Siqueira, K. 2003. "Conflict and Third-party Intervention." Defence and Peace Economics. Vol. 14, No. 6, pp. 389-400.

Tullock, G. 1980. "Efficient Rent Seeking," pp. 97-112 in J. Buchanan, R. Tollison, and G. Tullock, eds. Toward a Theory of Rent-seeking Society. College Station, TX: Texas A\&M University Press. 